\title{
Drought and Flood Stress Effects on Plant Development and Leaf Water Relations of Five Taxa of Trees Native to Bottomland Habitats
}

\author{
Lenore J. Nash ${ }^{1}$ and William R. Graves ${ }^{2}$ \\ Department of Horticulture, University of Maryland, College Park, MD 20742-5611 \\ Additional index words. Acer rubrum, Asimina triloba, Magnolia virginiana, Nyssa sylvatica, Taxodium distichum, water \\ stress, osmotic adjustment
}

\begin{abstract}
Responses of five bottomland tree taxa to drought and flooding were studied to identify those adapted to urban environments. During one experiment, containerized 'Franksred' red maple [Acer rubrum L. 'Franksred' (trademark = Red Sunset)], sweetbay magnolia (Magnolia virginiana L.), black tupelo (Nyssa sylvatica Marsh.), bald cypress [Taxodium distichum (L.) Rich.], and pawpaw [Asimina triloba (L.) Dunal.] were treated with various irrigation regimes for up to 118 days. Net assimilation rate (NAR) and relative growth rate (RGR) were reduced more by flooding than by drought for plants of all taxa, except pawpaw, which showed similar NAR and RGR during flooding and drought. Only sweetbay magnolia and bald cypress maintained positive NAR and RGR during flooding, and sweetbay magnolia was the only taxon that did not produce significantly less leaf surface area, shoot dry mass, and root dry mass during flooding and drought. Apparent morphological mechanisms of stress resistance included an increase in specific mass of leaves $\left(\mathrm{mg}^{\circ} \mathrm{cm}^{-2}\right)$ during drought for red maple and bald cypress and a 385\% increase in the root : shoot mass ratio for droughted plants of pawpaw. Leaf water relations of drought- and flood-stressed 'Franksred' red maple and sweetbay magnolia were determined in a second experiment. Predawn and mid-day leaf water potential $(\psi)$ decreased with decreasing root-zone matric potential for both taxa, and transpiration rate was reduced by drought and flooding. Pressure-volume analysis showed that leaves of 'Franksred' red maple responded to drought by shifting symplastic water to the apoplast. Leaves of drought-stressed sweetbay magnolia adjusted osmotically by reducing osmotic potential $\left(\psi_{\pi}\right)$ at full turgor by 0.26 MPa. Our results suggest that sweetbay magnolia and bald cypress will perform well at urban planting sites where episodes of drought and flooding regularly occur.
\end{abstract}

Horticulturists must identify diverse taxa of trees that withstand highly variable soil moisture conditions in urban areas. Both deficiencies and excesses in soil moisture contribute to decline of city trees (Berrang et al., 1985; Whitlow and Bassuk, 1987), and conservation of water amid continued urbanization is being promoted through municipal xeriscaping programs. Although the use of numerous species resistant to flooding and drought is needed to prevent monocultures prone to destruction by pests and diseases, Kielbaso (1990) reported that only seven species accounted for 75\% of the street trees planted in the United States in 1980.

More information is needed on the resistance to water stress of additional tree taxa with potential for use in urban areas. For many taxa, excessive soil moisture retards leaf development, induces stem hypertrophy, and causes chlorosis, wilting, epinasty, and senescence of leaves (Kawase, 1981; Kozlowski, 1985). Water deficits can reduce cell growth (Fitter and Hay, 1987), decrease leaf surface area (Borghetti et al., 1989; Hennessey et al., 1985), increase specific leaf weight (Joly et al., 1989), and alter dry matter production and partitioning (Davies and Castro-Jimenez, 1989; Graves and Wilkins, 1991; Joly et al., 1989; Schwintzer and Lancell, 1983). Drought also may alter stomatal resistance (Havis, 1980), partitioning of water in leaves between apoplast and symplast, bulk modulus of tissue elasticity ( $\left.\varepsilon_{\max }\right)$ (Joly and Zaerr, 1987), and turgor, osmotic, and total leaf water potentials $(\psi)$ (Abrams and Kubiske, 1990; Bahari et al., 1985; Ranney et al., 1991).

Received for publication 9 Sept. 1992. Accepted for publication 23 Apr. 1993. Scientific article A6370, Contribution 8554 from the Maryland Agr. Expt. Sta. The cost of publishing this paper was defrayed in part by the payment of page charges. Under postal regulations, this paper therefore must hereby be marked advertisement solely to indicate this fact.

${ }^{1}$ Present address: Dept. of Horticulture and Landscape Architecture, Univ. of Kentucky, Lexington, KY 40506.

${ }^{2}$ Present address: Dept. of Horticulture, Iowa State Univ., Ames, IA 5001 1-1 100.

To whom reprint requests should be addressed.
These morphological and physiological responses represent ways that tissues can resist low $\psi$, and the extent to which these responses are expressed during stress may indicate the relative degree of resistance a taxon possesses (Joly et al., 1989). Therefore, the intent of these studies was to quantify these responses in plants of five taxa of trees native to bottomland and riparian habitats. Such taxa often are recommended for use at wet sites because of their presumed flood resistance. Some bottomland species, such as river birch (Betula nigra L.), also have been observed to survive in landscapes with drier soils or where soil moisture content is highly variable (Dirr, 1990). This finding is particularly promising because the long-term survival of urban trees appears to depend on their capacity to withstand both excessive and deficient soil moisture. The objective of our first experiment was to measure the development and morphology of five taxa during exposure to a wide range of soil moisture conditions, focusing on traits that may represent mechanisms of stress resistance. In the second experiment, we characterized leaf water relations of two taxa we hypothesized would differ in resistance to drought and flood stress.

\section{Materials and Methods}

Whole-plant responses to water stress (Expt. 1). Five taxa of trees were grown singly in Zarn 800 (Zarn, Inc., Reidsville, N.C.) plastic nursery containers $(21 \mathrm{~cm}$ tall, $22 \mathrm{~cm}$ wide; volume, 8000 $\mathrm{cm}^{3}$ ) in $\approx 7600 \mathrm{~cm}^{3}$ of Sunshine Complete mix (Fisons Horticulture, Vancouver, B.C., Canada). One-year-old dormant, bare-root seedlings of black tupelo and bald cypress (Princeton Nurseries, Princeton, N.J.) were planted on 10 Dec. 1990. Two-year-old dormant rooted stem cuttings of 'Franksred' (trademark = Red Sunset) red maple (Schmidt Nursery, Boring, Ore.) were planted

Abbreviations: $\psi$, waterpotential; $\varepsilon_{\max }$, maximum bulk modulus of tissue elasticity; $\mathrm{NAR}$, net assimilation rate; RGR, relative growth rate. 
on 10 Feb. 1991. Seedlings of pawpaw, grown in a greenhouse from stratified seeds that were planted in a medium of 1 peatmoss : 1 pine bark : 1 vermiculite (by volume) on 12 Sept. 1990, also were planted on 10 Feb. 1991. Two-year-old dormant, bare-root seedlings of sweetbay magnolia (Heather Farms Nursery, McMinnville, Tenn.) were planted on 6 Mar. 1991. All plants were grown in a glasshouse at $22 \pm 6 \mathrm{C}$ through the experimental period. Irradiance, determined with a LI-COR LI-190S-1 quantum sensor (LI-COR, Lincoln, Neb.) to range from 1.8 to $20.0 \mathrm{~mol} / \mathrm{m}^{2}$ per day, was provided by natural irradiance supplemented with irradiance from incandescent lamps from 0600 to 0800 and from 1800 to 2400 HR. All clock hours refer to Eastern Standard Time (EST). All plants were irrigated with tap water when the surface of the growing medium appeared dry. Between the time several fully expanded leaves were present on all plants and the day the first experiment began, Peter's General Purpose 20N-4.3P-16.6K water-soluble fertilizer (W.R. Grace \& Co., Fogelsville, Pa.) at $250 \mathrm{mg}$ N/liter was applied at each irrigation. Peter's Soluble Trace Element Mix at 0.6 g.liter ${ }^{-1}$ was applied to all plants on 4 Mar. 1991.

Fifteen (pawpaw) or 27 (all others) plants were selected for uniform development, arranged randomly on greenhouse benches, and assigned randomly to each of four irrigation treatments on 22 Mar. 1991. Plants in each of these groups were assigned to durations of 0,59 , or 118 days. Irrigation treatments were flooded, container capacity, moderate drought, and severe drought. Penciltype tensiometers (Soil Moisture Systems, Tucson, Ariz.) were inserted into nine of 15 (pawpaw) or 15 of 27 (all others) containers assigned to container capacity, moderate drought, and severe drought treatments. The tensiometers were inserted such that the porus cups were near the center of the medium.

Treatments were applied from 1 Apr. to 28 July 1991. Matric potential of the medium was measured daily with a tensiometer (Soil Moisture Systems, Tucson, Ariz.). We intended to irrigate all plants in container capacity and moderate drought treatments to container capacity when the mean matric potential decreased to -4 and $-12 \mathrm{kPa}$, respectively. However, actual mean matric potentials immediately before irrigations were lower than planned for all taxa in both of these treatments (Table 1). Plants in the severe drought treatments were irrigated to container capacity either when mean matric potential was about $-45 \mathrm{kPa}$ or when leaf wilting occurred during the early morning in $50 \%$ of plants within a taxon. Plants in severe drought treatments were irrigated when mean matric potential was -34.5 to $-45.5 \mathrm{kPa}$ (Table 1). From 2.0 to 2.5 liters of

Table 1. Mean root-zone matric potentials at which irrigation occurred, and the total number of irrigations during the 118 days of treatment with various irrigation regimes for plants of five taxa of trees grown in containers.

\begin{tabular}{|c|c|c|c|c|c|}
\hline \multirow{2}{*}{$\begin{array}{l}\text { Dependent vari- } \\
\text { ble and irriga- } \\
\text { tion regime }\end{array}$} & \multicolumn{5}{|c|}{ Taxon } \\
\hline & $\begin{array}{l}\text { 'Franksred' } \\
\text { red maple }\end{array}$ & Pawpaw & $\begin{array}{l}\text { Sweetbay } \\
\text { magnolia }\end{array}$ & $\begin{array}{l}\text { Black } \\
\text { tupelo }\end{array}$ & $\begin{array}{c}\text { Bald } \\
\text { cypress }\end{array}$ \\
\hline \multicolumn{6}{|c|}{ Mean matric potential at which plants were irrigated $(\mathrm{kPa})$} \\
\hline Flooded & 0 & 0 & 0 & 0 & 0 \\
\hline Container capacity & -5.0 & -4.7 & -5.3 & -5.8 & -4.5 \\
\hline Moderate drought & -20.8 & -13.6 & -13.4 & -15.0 & -16.8 \\
\hline Severe drought & -34.5 & -38.6 & -42.7 & -45.5 & -34.8 \\
\hline \multicolumn{6}{|c|}{ No. irrigations during 118-day treatment } \\
\hline Flooded & --- & --- & --- & $\cdots-$ & --- \\
\hline Container capacity & 67 & 64 & 12 & 25 & 42 \\
\hline Moderate drought & 28 & 13 & 7 & 14 & 21 \\
\hline Severe drought & 9 & 6 & 3 & 4 & 8 \\
\hline
\end{tabular}

solution was applied at each irrigation. Containers of plants in the flooded treatment were immersed continuously in separate plastic buckets containing tap water to a level $2 \mathrm{~cm}$ above the top of the plant container.

Plants in the severe drought treatment were fertilized at each irrigation. Fertilizer was applied to plants in flooded, container capacity, and moderate drought treatments only when plants in the severe drought treatment were fertilized so that all plants of each taxon received similar amounts of fertilizer. For plants in the flooded treatment, containers were removed from the buckets, allowed to drain for $\approx 2 \mathrm{~min}$, and returned to buckets after solution was applied and allowed to drain. Because of chlorosis on young leaves, foliage of all sweetbay magnolia, black gum, and bald cypress was sprayed with Fe Sequestrene 330 (Ciba-Geigy, Greensboro, N.C.) at $1.2 \mathrm{~g}$ $\mathrm{Fe} /$ liter five times between 12 June and 28 July 1991.

One-third of the plants in each taxon-treatment combination were harvested on days 0,59 , and 118. Stem length of each plant was measured. Projected surface area of one or two fully expanded leaves selected at random was measured with a LI-COR 3000 leaf area meter. These leaves were dried separately in a forced-air oven at $65 \mathrm{C}$ for $48 \mathrm{~h}$, and specific mass was determined by dividing dry mass by surface area. Dry masses of all other leaves, shoot tissues, and root systems were determined after separating all growth medium from the roots and drying at $65 \mathrm{C}$ for $48 \mathrm{~h}$. Total projected surface area of leaves was determined for each plant by dividing total leaf dry mass by specific leaf mass. NAR was determined using the formula:

$$
M_{2}-M_{1} / t_{2}-t_{1} \times \log L_{2}-\log L_{1} / L_{2}-L_{1}
$$

where $M_{1}$ was the mean plant dry mass at day $59\left(t_{1}\right)$ within taxatreatment combinations, $\mathrm{M}_{2}$ was plant dry mass at day $118\left(\mathrm{t}_{2}\right)$, and $\mathrm{L}_{1}$ and $\mathrm{L}_{2}$ were the mean leaf surface areas within taxa-treatment combinations at $t_{1}$ and $t_{2}$, respectively. RGR was determined as the product of NAR and the leaf area ratio, which was determined as described by Harper (1977).

Leaf water relations of 'Franksred' red maple and sweetbay magnolia (Expt. 2). Sixty additional plants of 'Franksred' red maple and 60 of sweetbay magnolia were selected for uniformity, arranged at random in the greenhouse, and established at the same time as plants used for Expt. 1. All plants were irrigated as described for the first experiment when the surface of the medium appeared dry until irrigation treatments began on 13 May 1991. Treatments were applied as described for the first experiment, except that no moderate drought treatment was applied. Twenty plants of both taxa were assigned at random to each treatment. Tensiometers were placed in 11 of 20 containers within each treatment as described for Expt. 1.

The $\psi$ of a recently expanded leaf on 18 randomly chosen plants of each taxon was measured from 0400 to 0530 (predawn) and from 1200 to 1400 HR (mid-day) with a pressure chamber (P.M.S. Instrument, Corvallis, Ore.) on days 0, 23, 46, 69, and 92. Transpiration rate of a recently expanded leaf on plants in containers with tensiometers was measured from 1100 to $1300 \mathrm{HR}$ with a LI-COR 1600 steady-state porometer every 4 to 5 days. On days $0,23,46$, 69 , and 92, transpiration also was determined on plants used for leaf $\psi$ measurements.

Six to eight plants of both taxa from each treatment were selected at random on day 92 for pressure-volume analysis of leaves. Procedures for sampling leaves were consistent with those of Joly and Zaerr (1987). The petiole of a leaf that had recently expanded on each plant was cut under deionized water using a razor blade. Leaves were placed in vials filled with deionized 
water. Vials were placed within polyethylene bags in a portable ice chest containing crushed ice. The ice chest was transferred to a dark cooler at $4 \mathrm{C}$ immediately after leaves were collected. Analysis of leaves began $\approx 18 \mathrm{~h}$ after harvest. Two pressure chambers were used simultaneously, and six to eight leaves selected at random were analyzed daily (Cheung et al., 1975; Tyree and Hammel, 1972). All leaves were analyzed within 5 to 7 days. Osmotic potential at full turgor $\left(\psi_{\pi}^{100}\right)$, relative water content (RWC), and percentage apoplastic water were determined with PVOL software (Joly and Zaerr, 1987). Previous studies have shown that pressure-volume relationships are altered by leaf rehydration in some species (Evans et al., 1990; Kubiske and Abrams, 1990). We did not determine effects of rehydration in 'Franksred' red maple and sweetbay magnolia, but the $\psi_{\pi}{ }^{100}$ and the percentage apoplastic water of each leaf were plotted against the number of days between the date of collection and processing. No trends were apparent, indicating that storage for up to 7 days did not alter pressure-volume relationships. The highest RWC in the linear portion of each curve was used to determine $\varepsilon_{\text {max }}$ (Wilson et al., 1979). A $\log$ transformation was made on $\varepsilon_{\max }$ values because variances of nontransformed values were not homogeneous.

Data were analyzed using the Statistical Analysis System (SAS Institute, Cary, N.C.). Because the matric potential at which plants in container capacity, moderate drought, and severe drought treatments were irrigated varied among taxa, analyses of variance were performed within harvests and taxa using the General Linear Model (GLM), and least-squared means were generated. Means were separated using Fisher's LSD $(P \leq 0.05)$ with Procedure Duncan on S AS.

\section{Results and Discussion}

Whole-plant responses to water stress (Expt. 1). Harvesting plants on days 0,59 , and 118 allowed NAR and RGR to be calculated for days 0 through 59, 59 through 118, and 0 through 118 (Harper, 1977). Only data for days 59 through 118 will be discussed because trends in how irrigation regimes affected NAR and RGR were similar for all intervals (Nash, 1992). NAR, which is a measure of the efficiency of plants as assimilating systems, and RGR, which expresses growth as a function of dry matter and time, indicate the degree to which water stress affected dry-matter accumulation. NAR and RGR tended to be highest for 'Franksred' red maple, pawpaw, black tupelo, and bald cypress at container capacity. For 'Franksred' red maple and bald cypress, NAR and RGR of plants in the container capacity and moderate drought treatments were similar (Fig. 1). Severe drought reduced NAR and RGR of these four taxa significantly compared to plants at container capacity. Statistical comparisons between taxa were not performed, but severe drought appeared to affect NAR and RGR most in pawpaw, which had a NAR of $\approx 0.04 \mathrm{mg} / \mathrm{cm}^{2}$ per day and an RGR of near $0 \mathrm{mg} / \mathrm{mg}$ per day (Fig. 1). The NAR and RGR of sweetbay magnolia were similar for plants in container capacity, moderate drought, and severe drought treatments. Flooding reduced NAR and RGR of all taxa. 'Franksred' red maple, pawpaw, and black tupelo under flooding had negative NAR and RGR values, indicating that these plants were senescing. Twenty-two percent of the 'Franksred' red maple and $33 \%$ of the black tupelo died during the 118-day exposure to flooding.

Severe drought tended to reduce root dry mass, with a reduction as large as $81 \%$ for pawpaw compared to plants at container capacity (Table 2). Sweetbay magnolia, black tupelo, and bald cypress under severe drought did not exhibit a significant reduction in root mass. Root mass of sweetbay magnolia tended to be
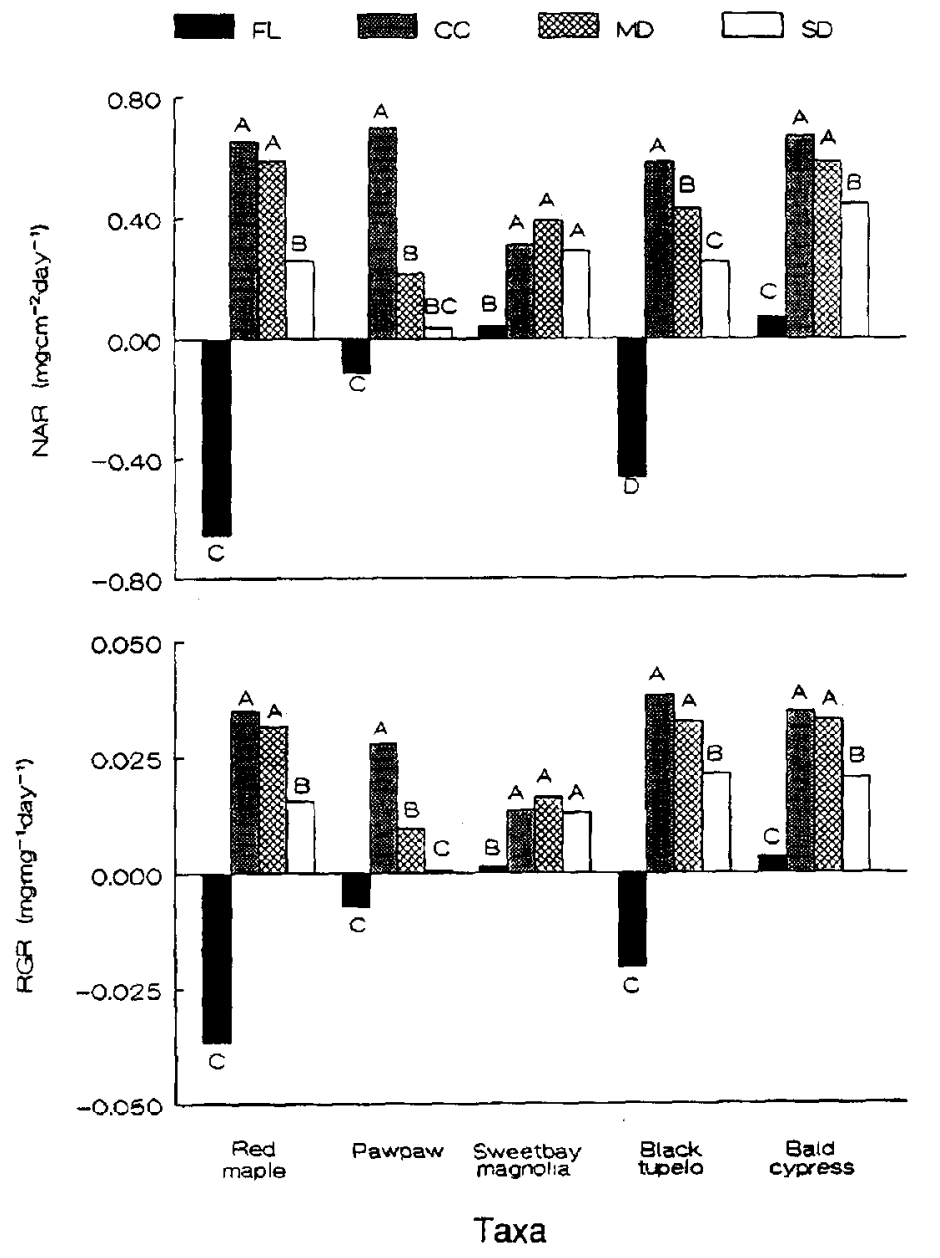

Fig. 1. Net assimilation rate (NAR) and relative growth rate (RGR) of plants grown in containers and exposed for 118 days to flood (FL), container capacity (CC), moderate drought (MD), and severe drought (SD) treatments (details in text and Table 1). Values are means of five (pawpaw) or nine replications for days 59 through 118 of the experiment. Within each taxon, mean separation by Fisher's LsD, $P \leq 0.05$ ).

highest for plants under moderate drought, and root mass of plants under severe drought was only $19 \%$ less than that of plants under moderate drought. Flooding reduced root mass in all taxa, except sweetbay magnolia. Moderate drought did not affect shoot (stem plus leaf) dry mass of any taxon, while severe drought caused significant reductions in shoot mass of 'Franksred' red maple, black tupelo, and bald cypress.

In contrast to the other four taxa, shoot mass of sweetbay magnolia tended to be highest for plants under moderate drought, and mean shoot mass under severe drought was only $9 \%$ less than that of plants under moderate drought (Table 2). Shoot mass of flooded sweetbay magnolia tended to be considerably less than that of seedlings in the other treatments. Mean shoot dry mass of pawpaw under severe drought was $89 \%$ less than that of plants at container capacity, but this difference was not statistically significant due to variation among seedlings.

Flooded black tupelo had a lower root : shoot ratio than plants at container capacity, and a similar trend was observed in pawpaw (Table 2). Water deficits tended to increase root : shoot ratio in pawpaw, while decreasing it in black tupelo. Increases in root : shoot ratio during drought have been observed in other taxa, such as sweetgale (Myrica gale L.) (Schwintzer and Lancell; 1983), Douglas fir [Pseudotsuga menziesii (Mirb.) Franco] (Joly et al., 1989), and thornless honey locust (Gleditsia triacanthos L. var. 
Table 2. Dry mass, root : shoot ratio, estimated leaf area, and specific leaf mass of plants of five taxa of trees grown in containers and treated with various irrigation regimes for 118 days. Values are means of five (pawpaw) or nine replicate plants.

\begin{tabular}{|c|c|c|c|c|c|}
\hline \multirow{2}{*}{$\begin{array}{l}\text { Dependent vari- } \\
\text { able and irriga- } \\
\text { tion regime }\end{array}$} & \multicolumn{5}{|c|}{ Taxon } \\
\hline & $\begin{array}{l}\text { 'Franksred' } \\
\text { red maple }\end{array}$ & Pawpaw & $\begin{array}{l}\text { Sweetbay } \\
\text { magnolia }\end{array}$ & $\begin{array}{l}\text { Black } \\
\text { tupelo }\end{array}$ & $\begin{array}{c}\text { Bald } \\
\text { cypress }\end{array}$ \\
\hline \multicolumn{6}{|c|}{ Root dry mass (g) } \\
\hline Flooded & $1.1 b^{2}$ & $9.4 \mathrm{c}$ & $5.9 \mathrm{a}$ & $1.0 \mathrm{~b}$ & $7.3 \mathrm{~b}$ \\
\hline Container ca] & $38.2 \mathrm{a}$ & $175.3 \mathrm{a}$ & $8.4 \mathrm{a}$ & $25.7 \mathrm{a}$ & $39.9 \mathrm{a}$ \\
\hline ht & $30.1 \mathrm{ab}$ & $55.1 \mathrm{ab}$ & $10.8 \mathrm{a}$ & $19.5 \mathrm{ab}$ & $37.5 \mathrm{a}$ \\
\hline & & $33.3 \mathrm{bc}$ & & $8.1 \mathrm{ab}$ & $23.3 \mathrm{ab}$ \\
\hline \multicolumn{6}{|c|}{ Shoot dry mass ( $\mathrm{g}$ ) } \\
\hline 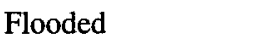 & $0.2 \mathrm{c}$ & $11.4 \mathrm{~b}$ & 1.7 & $0.1 \mathrm{c}$ & $6.5 \mathrm{c}$ \\
\hline ity & & $47.1 \mathrm{a}$ & & $30.1 \mathrm{a}$ & $53.1 \mathrm{a}$ \\
\hline ught & $60.8 \mathrm{a}$ & $16.8 \mathrm{a}$ & $\mathbf{a}$ & $28.2 \mathrm{a}$ & $52.1 \mathrm{a}$ \\
\hline ought & $29.0 \mathrm{~b}$ & $5.3 \mathrm{a}$ & $7.0 \mathrm{a}$ & $14.0 \mathrm{~b}$ & $22.2 \mathrm{~b}$ \\
\hline \multicolumn{6}{|c|}{ Root : shoot ratio } \\
\hline 1 & $0.4 \mathrm{a}$ & $0.4 \mathrm{~b}$ & $1.2 \mathrm{a}$ & $0.9 \mathrm{~b}$ & $0.4 \mathrm{a}$ \\
\hline & $0.2 \mathrm{a}$ & $1.8 \mathrm{ab}$ & & $2.0 \mathrm{a}$ & $0.3 \mathrm{a}$ \\
\hline ought & $0.2 \mathrm{a}$ & $2.1 \mathrm{a}$ & 0 . & $0.4 \mathrm{c}$ & $0.3 \mathrm{a}$ \\
\hline Severe drought & $0.2 \mathrm{a}$ & $3.3 \mathrm{a}$ & $0.6 \mathrm{a}$ & $0.3 \mathrm{c}$ & $0.5 \mathrm{a}$ \\
\hline \multicolumn{6}{|c|}{ Estimated leaf surface area $\left(\mathrm{cm}^{2}\right)$} \\
\hline Floo & $71 \mathrm{~d}$ & $1846 \mathrm{~b}$ & $279 a$ & $75 \mathrm{c}$ & $907 \mathrm{c}$ \\
\hline Containe & $9606 \mathrm{a}$ & 9075 a & $1233 \mathrm{a}$ & $5753 a$ & 7936 a \\
\hline Moderate drought & $7937 \mathrm{~b}$ & $3089 \mathrm{~b}$ & $1266 \mathrm{a}$ & $5283 \mathrm{a}$ & 8237 a \\
\hline drought & $3419 \mathrm{c}$ & 1204 b & $1132 \mathrm{a}$ & $2672 b$ & $2575 \mathrm{~b}$ \\
\hline \multicolumn{6}{|c|}{ Specific leaf mass $\left(m g \cdot \mathrm{cm}^{-2}\right)$} \\
\hline Flo & $7.4 \mathrm{~b}$ & $6.1 \mathrm{a}$ & $6.3 \mathrm{a}$ & $5.3 \mathrm{a}$ & $7.2 \mathrm{~b}$ \\
\hline Container capacity & $7.1 \mathrm{~b}$ & $5.2 \mathrm{a}$ & $6.4 \mathrm{a}$ & $5.7 \mathrm{a}$ & $6.6 \mathrm{~b}$ \\
\hline & $7.7 \mathrm{~b}$ & $5.5 \mathrm{a}$ & $6.1 \mathrm{a}$ & $5.2 \mathrm{a}$ & $6.5 \mathrm{~b}$ \\
\hline Severe drought & $8.9 \mathrm{a}$ & $5.6 \mathrm{a}$ & $6.2 \mathrm{a}$ & $5.2 \mathrm{a}$ & $8.7 \mathrm{a}$ \\
\hline
\end{tabular}

$\overline{{ }^{2} \text { Mean separation within columns and dependent variables by Fisher's LSD, } P \leq 0.05}$.

inermis Willd.) (Graves and Wilkins, 1991). A higher root : shoot ratio may represent a mechanism of stress avoidance because the proportion of total mass that can explore the root zone for water is increased. Only pawpaw showed an increase in root : shoot ratio in our experiment. All seedlings of pawpaw formed coarse root systems with dominant taproots. Pawpaw in the field also produce long taproots (H.J. Swartz, personal communication) that may be well-adapted for exploring the soil profile for available water.

'Franksred' red maple, pawpaw, black tupelo, and bald cypress responded to flooding and severe drought with reductions in leaf area (Table 2). Moderate drought reduced leaf area of 'Franksred' red maple and pawpaw by $17 \%$ and $66 \%$, respectively, relative to plants at container capacity. Drought has been shown to reduce leaf area in other tree taxa such as alder (Alnus B. Ehrh. spp.) (Borghetti et al., 1989; Hennessey et al., 1985), eucalyptus (Eucalyptus L'Hér. spp.) (Myers and Landsberg, 1989), and tulip poplar (Liriodendron tulipifera L.) (Pope and Madgwick, 1974). In contrast, sweetbay magnolia at container capacity and under moderate drought had similar leaf area, and plants under severe drought showed only an $8 \%$ reduction in leaf area compared to plants at container capacity. Reduced leaf area may be among the first morphological traits affected by water stress because cell expansion depends on the availability of water to maintain turgor (Hale and Orcutt, 1987). Leaf abscission also reduced leaf area in droughted and flooded red maple and flooded black tupelo. Limiting transpiration by reducing leaf area is a mechanism that can function to conserve soil water and avoid low leaf $\psi$.

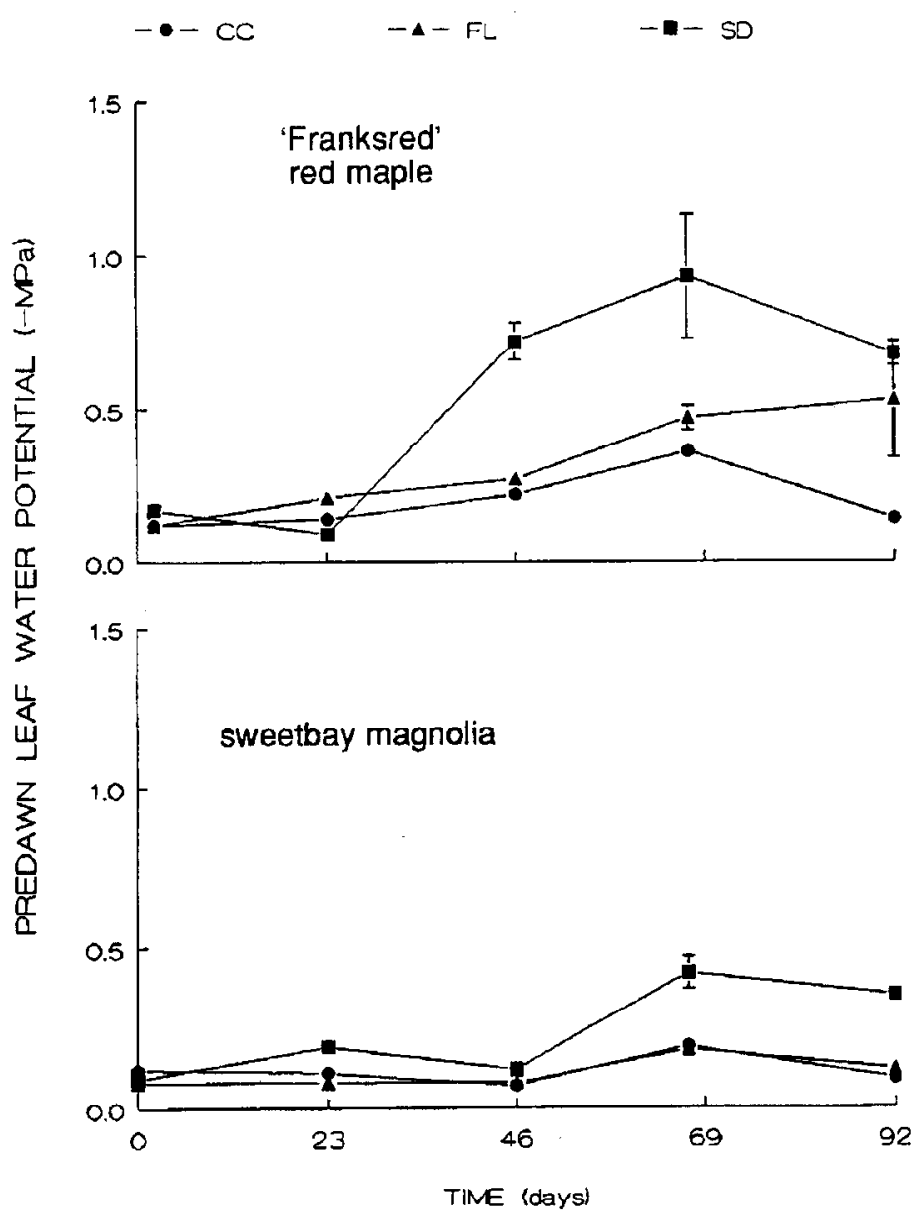

Fig. 2. Predawn leaf water potential of plants of 'Franksred' red maple and sweetbay magnolia in container capacity (CC), flooded (FL), and severe drought (SD) treatments. Values represent means of six replicates, and vertical bars represent \pm 1 SE.

Severe drought for 118 days increased specific leaf mass of 'Franksred' red maple and bald cypress (Table 2), suggesting that increased leaf thickness or cellular density may have reduced transpirational water loss per unit leaf mass. Flooded plants of all taxa, except bald cypress, showed greater specific leaf mass than plants in other treatments on day 59. Means of specific leaf mass tended to be higher on day 59 than on day 0 , regardless of taxa and treatment (data not presented). There was little change in specific leaf mass of flooded plants between days 59 and 118, but specific leaf mass of plants at container capacity, or under moderate or severe drought increased between these times in all taxa, except pawpaw. Hence, specific leaf mass tended to increase over time, with the most pronounced change among severely droughted 'Franksred' red maple and bald cypress. Increased specific leaf mass implies leaves of droughted 'Franksred' red maple and bald cypress were thicker or had more densely arranged cells. Plasticity of specific leaf mass within populations of Douglas fir (Joly et al., 1989) and 'Franksred' red maple (Abrams and Kubiske, 1990) has been reported, but no change in specific leaf mass was found in drought-stressed seedlings of American elm (Ulmus americana L.) (Walters and Reich, 1989).

Leaf water relations of red maple and sweetbay magnolia (Expt. 2). Predawn $\psi_{1}$ ranged from -0.1 to $-0.9 \mathrm{MPa}$ (Fig. 2), and midday $\psi_{1}$ were -0.3 to $-1.7 \mathrm{MPa}$ (Fig. 3). Droughted plants of both taxa tended to exhibit the lowest predawn and midday $\psi_{1}$, indicating that the quantity of water in the root zone or the capacity of the conducting system to transport water was insufficient to allow 


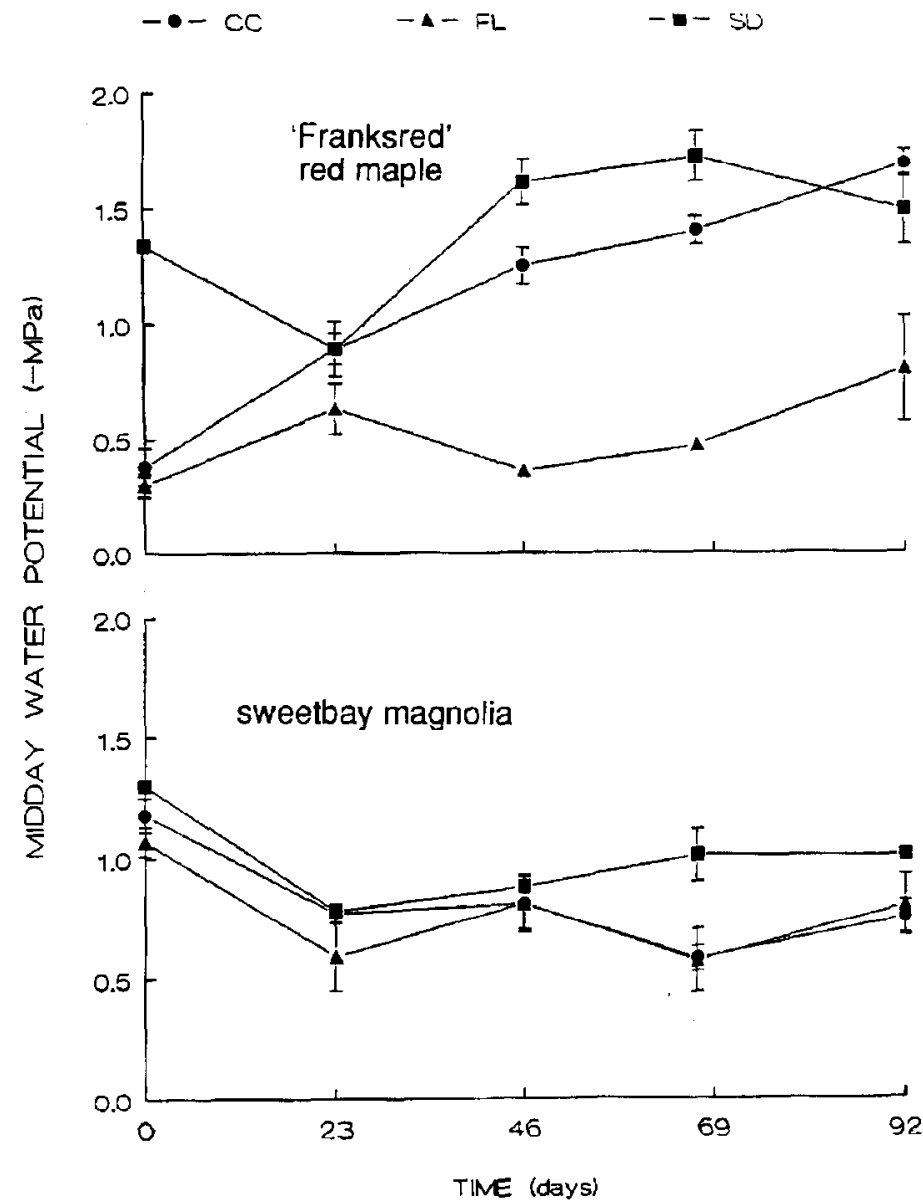

Fig. 3. Midday leaf water potential of plants of 'Franksred' red maple and sweetbay magnolia in container capacity (CC), flooded (FL), and severe drought (SD) treatments. Values represent means of six replicates, and vertical bars represent \pm 1 SE.

rehydration of leaves during the night. Differences between treatments in predawn and midday $\psi_{1}$ were smaller for sweetbay magnolia than for 'Franksred' red maple (Figs. 2 and 3). Flooded plants of 'Franksred' red maple tended to have the least negative midday $\psi_{1}$ (Fig. 3) and markedly reduced rates of transpiration (Fig. 4). Transpiration rates were highest for both taxa at container capacity, and, similar to $\psi_{1}$, differences between treatments were more pronounced in 'Franksred' red maple than sweetbay magnolia (Fig. 4). Transpiration rates and leaf $\psi$ of droughted plants were consistently low at all sampling dates and root-zone matric potentials, indicating that drought may have reduced root hydraulic conductivity as has been reported for lemon (Citrus jambhiri Lush.) (Ramos and Kaufmann, 1979).

No osmotic adjustment was found in leaves of drought-stressed 'Franksred' red maple, but the mean $\psi_{\pi}{ }^{100}$ of flooded 'Franksred' red maple, $-1.82 \mathrm{MPa}$, was significantly lower than that of plants at container capacity on day 92 (Table 3). Drought caused an osmotic adjustment of $0.26 \mathrm{MPa}$ in leaves of sweetbay magnolia. These findings are consistent with those of Roberts et al. (1980), who reported that loss of leaf turgor was not prevented by osmotic adjustment in red maple in the field. Abrams and Kubiske (1990) found no osmotic adjustment in droughted red maple from upland sites in Pennsylvania, but Whitlow et al. (1991) reported that red maple from wet and dry sites adjusted osmotically during drought. We know of no other studies of osmotic adjustment in sweetbay magnolia, but Augé and Stodola (1989) found southern magnolia (M. grandiflora L.) underwent an osmotic adjustment of $1.0 \mathrm{MPa}$

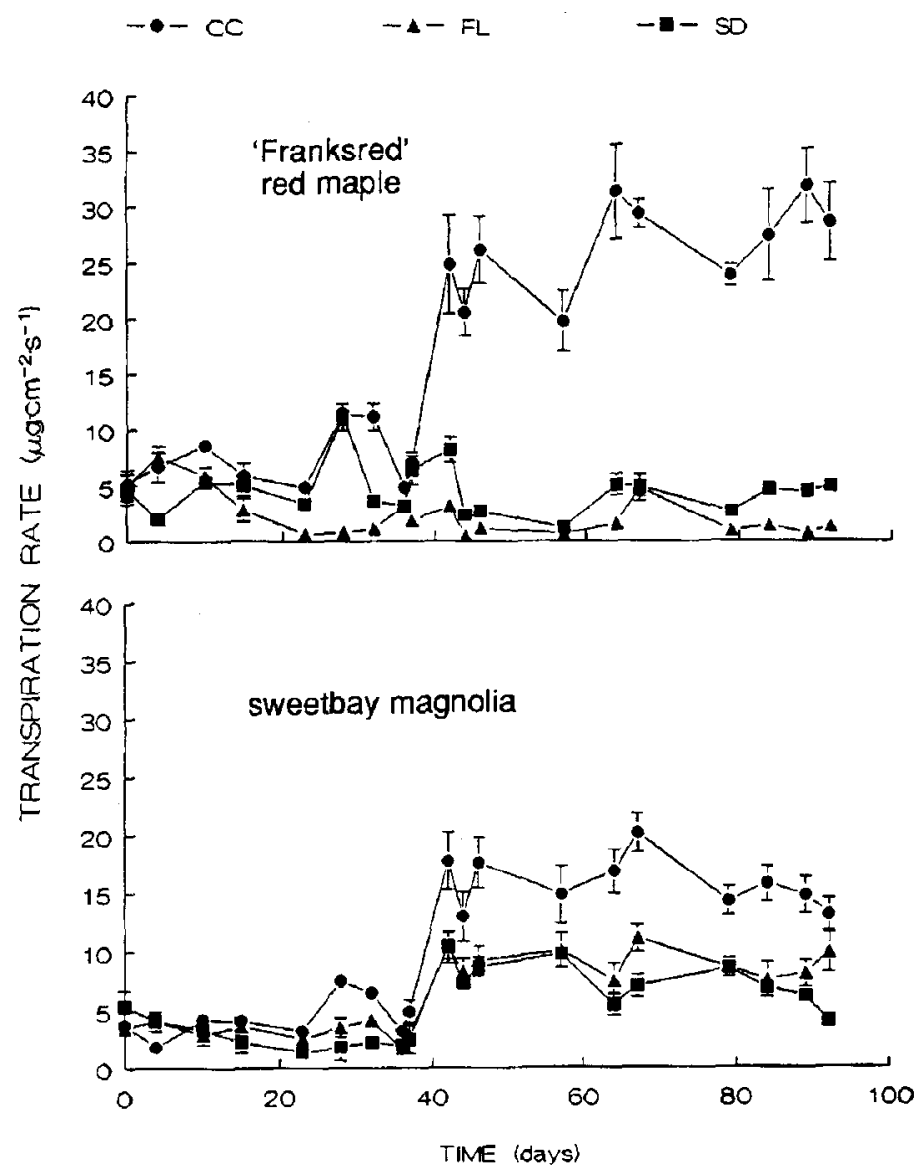

Fig. 4. Transpiration rate of leaves of 'Franksred' red maple and sweetbay magnolia in container capacity (CC), flooded (FL), and severe drought (SD) trcatments. Values represent means of 11 replicates, and vertical bars represent \pm 1 SE.

as plants entered winter dormancy.

Pressure-volume analysis allowed examination of water stress effects on partitioning of water between the symplast and apoplast and on $\varepsilon_{\text {max }}$. Stress may alter these traits, affecting turgor maintenance during extended periods of internal water deficits. The percentage of water in the apoplast of leaves of red maple under severe drought was about double that of plants at container capacity or under flooding, but the percentage of apoplastic water in leaves of sweetbay magnolia did not increase in response to drought (Table 3). This result is consistent with previous studies showing that apoplastic water percentage increases in response to drought in only certain woody taxa. For example, Joly and Zaerr (1987) reported an 18\% increase in apoplastic water content of Douglas fir subjected to drought, but Augé et al. (1986) found that drought acclimation did not affect apoplastic water percentage in leaves of drought-stressed rose (Rosa hybrida L. 'Samantha'). Our data suggest that drought may have increased the rate at which solute concentration increased in the symplast as RWC decreased during water deficit for 'Franksred' red maple (Radin, 1983). The influence of altered apoplastic water percentage on drought resistance in 'Franksred' red maple merits further study. The $\varepsilon_{\max }$ of 'Franksred' red maple and sweetbay magnolia was increased by water stress (Table 3). Reports by Bahari et al. (1985), Joly and Zaerr (1987), and Zimmermann (1978) provide conflicting results concerning the influence of drought on $\varepsilon_{\text {max }}$ in woody plants, and Ranney et al. (1990) concluded that turgor maintenance in five species of trees was related more to differences in $\psi_{\pi}$ than to elastic properties. Augé and Stodola (1989) found $\varepsilon_{\text {max }}$ of sweetgum (Liquidambar styraciflua L.) and southern magnolia increased 
Table 3. Pressure-volume analysis of leaves of plants of 'Franksred' red maple and sweetbay magnolia that had been grown for 92 days with various irrigation regimes. Means $\pm \mathrm{SE}$ for osmotic potential at full turgor $\left(\psi_{\pi}^{100}\right)$, percentage apoplastic water (APO), and log of elastic modulus $\left(\varepsilon_{\max }\right)$ are shown.

\begin{tabular}{lccc}
\hline & \multicolumn{3}{c}{ Irrigation regime } \\
\cline { 2 - 4 } $\begin{array}{l}\text { Taxon and } \\
\text { dependent variable }\end{array}$ & Flooded & $\begin{array}{c}\text { Container } \\
\text { capacity }\end{array}$ & $\begin{array}{c}\text { Severe } \\
\text { drought }\end{array}$ \\
\cline { 2 - 4 } & 'Franksred' red maple \\
$\mathrm{n}$ & 4 & 7 & 8 \\
$\Psi_{\pi}{ }^{100}(\mathrm{MPa})$ & $-1.82 \pm 0.05 \mathrm{~b}^{\mathrm{z}}$ & $-1.68 \pm 0.04 \mathrm{a}$ & $-1.54 \pm 0.14 \mathrm{a}$ \\
$\mathrm{APO}(\%)$ & $26.4 \pm 1.65 \mathrm{~b}$ & $21.8 \pm 3.88 \mathrm{~b}$ & $55.1 \pm 7.67 \mathrm{a}$ \\
$\varepsilon_{\max }(\log \mathrm{MPa})$ & $1.28 \pm 0.06 \mathrm{a}$ & $0.77 \pm 0.02 \mathrm{~b}$ & $1.25 \pm 0.09 \mathrm{a}$ \\
& \multicolumn{4}{c}{ Sweetbay magnolia } & \\
$\mathrm{n} \quad$ & 6 & 8 & 6 \\
$\Psi_{\pi}{ }^{100}(\mathrm{MPa})$ & $-1.74 \pm 0.07 \mathrm{a}$ & $-1.69 \pm 0.05 \mathrm{a}$ & $-1.95 \pm 0.06 \mathrm{~b}$ \\
$\mathrm{APO}(\%)$ & $21.4 \pm 3.02 \mathrm{a}$ & $13.1 \pm 1.92 \mathrm{a}$ & $17.8 \pm 3.43 \mathrm{a}$ \\
$\varepsilon_{\max }(\log \mathrm{MPa})$ & $1.10 \pm 0.08 \mathrm{a}$ & $0.91 \pm 0.03 \mathrm{~b}$ & $1.09 \pm 0.03 \mathrm{a}$ \\
\hline
\end{tabular}

${ }^{\mathrm{z}}$ Mean separation within rows by Fisher's LSD, $P \leq 0.05$.

during onset of winter dormancy. Possibly, the increases in $\varepsilon_{\max }$ we observed were a consequence of the cessation of growth, because water stress inhibited stem elongation and caused the formation of terminal buds (Nash, 1992).

Sweetbay magnolia may merit increaseduse where extremes of soil water content occur. Results of Expt. 1 indicate bald cypress also would be appropriate for use at such sites. The apparent resistance of these taxa to drought is intriguing, given that bald cypress is indigenous to swamps and sweetbay magnolia is found exclusively along bodies of water and in swampy soils in its native range (Preston, 1989). Growth of both taxa was reduced by flooding, but our treatments may have been more stressful than conditions in nature because turbulence might increase soil oxygen levels at swampy and riparian sites. Red maple and black tupelo are indigenous to broad areas of eastern North America in habitats with soils that vary in moisture (Dirr, 1990; Preston, 1989). Both taxa were quite sensitive to flooding, and their growth also was reduced by severe drought. Given that growth and leaf water relations during drought vary with provenance for red maple (Abrams and Kubiske, 1990; Townsend and Roberts, 1973; Whitlow et al., 1991) and other taxa with large native ranges, identification of genotypes of red maple and black tupelo with superior capacities to resist water stress is warranted.

\section{Literature Cited}

Abrams, M.D. and M.E. Kubiske. 1990. Photosynthesis and water relations during drought in Acer rubrum L. genotypes from contrasting sites in central Pennsylvania. Functional Ecol. 4:727-733.

Augé, R.M. and A.J.W. Stodola. 1989. Analysis of water potential isotherms in two ornamental shade tree species entering winter dormancy. J. Amer. Soc. Hort. Sci. 114:666-673.

Augé, R.M., K.A. Schekel, and R.L. Wample. 1986. Osmotic adjustment in leaves of VA mycorrhizal and nonmycorrhizal rose plants in response to drought stress. Plant Physiol. 82:765-770.

Bahari, Z.A., S.G. Pallardy, and W.C. Parker. 1985. Photosynthesis, water relations, and drought adaptation in six woody species of oak-hickory forests in central Missouri. For. Sci. 31:557-569.

Berrang, P., D.F. Karnosky, and B.J. Stanton. 1985. Environmental factors affecting tree health in New York City. J. Arboricult. 11:185-189.

Borghetti, M., S. Cocco, M. Lambardi, and S. Raddi. 1989. Response to water stress of Italian alder seedlings from diverse geographic origins. Can. J. For. Res. 19:1071-1076.
Cheung, Y.N.S., M.T. Tyree, and J. Dainty. 1975. Water relations parameters on single leaves obtained in a pressure bomb and some ecological interpretations. Can. J. Bot. 53:1342-1346.

Davies, F.T., Jr., and Y. Castro-Jimenez. 1989. Water relations of Lagerstroemia indica grown in amended media under drought stress. Scientia Hort. 41:97-104. Dirr, M.A. 1990. Manual of woody landscape plants: Their identification, ornamental characteristics, culture, propagation, and uses. 4th ed. Stipes, Champaign, Ill. Evans, R.D., R.A. Black, and S.O. Link. 1990. Rehydration-induced changes in pressure-volume relationships of Artemisia tridentata Nutt. ssp. tridentata. Plant Cell Environ. 13:455-461.

Fitter, A.H. and R.K.M. Hay. 1987. Environmental physiology of plants. 2nd ed. Academic, London.

Graves, W.R. and L.C. Wilkins. 1991. Growth of honey locust seedlings during high root-zone temperature and osmotic stress. HortScience 26:1312-1315.

Hale, M.G. and D.M. Orcutt. 1987. The physiology of plants under stress. Wiley, New York.

Harper, J.L. 1977. Population biology of plants. Academic, London.

Havis, J.R. 1980. Container moisture state and stomatal resistance in nursery plants. HortScience 15:638-639.

Hennessey, T.C., L.K. Bair, and R.W. McNew. 1985. Variation in response among three Alnus spp. clones to progressive water stress. Plant \& Soil 87:135-141.

Joly, R.J. and J.B. Zaerr. 1987. Alteration of cell-wall water content and elasticity in Douglas-fir during periods of water deficit. Plant Physiol. 83:418-422.

Joly, R.J., W.T. Adams, and S.G. Stafford. 1989. Phenological and morphological responses of mesic and dry site sources of coastal Douglas-fir to water deficit. For. Sci. 35:987-1005.

Kawase, M. 1981. Anatomical and morphological adaptation of plants to waterlogging. HortScience 16:30-34.

Kielbaso, J.J. 1990. Trends and issues in city forests. J. Arboricult. 16:69-76.

Kozlowski, T.T. 1985. Soil aeration, flooding, and tree growth. J. Arboricult. 11:85-95.

Kubiske, M.E. and M.D. Abrams. 1990. Pressure-volume relationships in nonrehydrated tissue at various water deficits. Plant Cell Environ. 13:995-1000.

Myers, B.J. and J.J. Landsberg. 1989. Water stress and seedling growth of two eucalypt species from contrasting habitats. Tree. Physiol. 5:207-218.

Nash, L.J. 1992. Morphological and physiological responses of five native wetland tree species to water stress. MS Thesis, Univ. of Maryland, College Park.

Pope, P.E. and H.A.I. Madgwick. 1974. The influence of moisture stress on Liriodendron tulipifera L. seedlings. Ann. Bot. 38:431-439.

Preston, R.J., Jr. 1989. North American trees. 4th ed. Iowa State Univ. Press, Ames. Radin, J.W. 1983. Physiological consequences of cellular water deficits: Osmotic adjustment, p. 267-276. In H.M. Taylor, W.R. Jordan, and T.R. Sinclair (eds.). Limitations to efficient water use. in crop production. Amer. Soc. Agron.-Crop Sci. Soc. Amer.-Soil Sci. Soc. Amer. (ASA-CSSA-SSSA), Madison, Wis.

Ramos, C. and M.R. Kaufmann. 1979. Hydraulic resistance of rough lemon roots. Plant Physiol. 45:311-314.

Ranney, T.G., T.H. Whitlow, and N.L. Bassuk. 1990. Response of five temperate deciduous tree species to water stress. Tree Physiol. 6:439-448.

Ranney, T.G., N.L. Bassuk, and T.H. Whitlow. 1991. Osmotic adjustment and solute constituents in leaves and roots of water-stressed cherry (Prunus) trees. J. Amer. Soc. Hort. Sci. 116:684-688.

Roberts, S.W., B.R. Strain, and K.R. Knoerr. 1980. Seasonal patterns of leaf water relations in four co-occurring forest tree species: Parameters from pressurevolume curves. Oecologia 46:330-337.

Schwintzer, C.R. and S.A. Lancell. 1983. Effect of water-table depth on shoot growth, root growth, and nodulation of Myrica gale seedlings. J. Ecol. 71:489-501. Townsend, A.M. and B.R. Roberts. 1973. Effect of moisture stress on red maple seedlings from different seed sources. Can. J. Bot. 51:1989-1995.

Tyree, M.T. and H.T. Hammel. 1972. The measurement of the turgor pressure and the water relations of plants by the pressure-bomb technique. J. Expt. Bot. 23:1267-282.

Walters, M.B. and P.B. Reich. 1989. Response of Ulmus americana seedlings to varying nitrogen and water status. 1. Photosynthesis and growth. Tree Physiol. 5:159-172.

Whitlow, T.H. and N.L. Bassuk. 1987. Trees in difficult sites. J. Arboricult. 13:10-17. Whitlow. T.H., C.M. Kearns, A. Howard, and N.L. Bassuk. 1991. Adaptive responses of red maple ecotypes to water stress. HortScience 26:746. (Abstr.) Wilson, J.R., M.J. Fisher, E.D. Schulze, G.R. Dolby, and M.M. Ludlow. 1979. Comparison between pressure-volume and dewpoint-hygrometry techniques for determining the water relations characteristics of grass and legume leaves. Oecologia 41:77-88

Zimmermann, U. 1978. Physics of turgor- and osmo-regulation. Annu. Rev. Plant Physiol. 29:121-148. 